\title{
Genomic Analysis of Milk Protein Fractions in Brown Swiss Cattle
}

\author{
Lucio Flavio Macedo Mota $₫$, Sara Pegolo* $*$, Vittoria Bisutti, Giovanni Bittante $₫$ \\ and Alessio Cecchinato
}

Department of Agronomy, Food, Natural Resources, Animals and Environment (DAFNAE), University of Padova, Viale dell' Università 16, 35020 Legnaro, Italy; flaviommota.zoo@gmail.com (L.F.M.M.);

vittoria.bisutti@unipd.it (V.B.); giovanni.bittante@unipd.it (G.B.); alessio.cecchinato@unipd.it (A.C.)

* Correspondence: sara.pegolo@unipd.it

Received: 17 January 2020; Accepted: 18 February 2020; Published: 20 February 2020

Simple Summary: Milk protein fractions are hugely important in the dairy industry because of the key role they play in milk technological properties. The selection of cows for milk protein fractions may, therefore, improve both the nutritional and technological characteristics of milk, and, consequently, the processing efficiency and value of the dairy product. This study estimated the genetic parameters of the major milk protein fractions (four caseins, and two whey proteins) determined variously as: (i) milk content $(\mathrm{g} / 100 \mathrm{~g}$ milk), (ii) percentage of milk nitrogen $(\% \mathrm{~N})$ and (iii) daily yield (g/d) in Brown Swiss dairy cattle. The results showed that the (co)variances and genetic parameter estimates differed according to how the proteins were measured. These results provide useful information for developing selection strategies in dairy cattle breeding programs aimed at improving both the nutritional and technological properties of milk.

\begin{abstract}
Depending on whether milk protein fractions are evaluated qualitatively or quantitatively, different genetic outcomes may emerge. In this study, we compared the genetic parameters for the major milk protein fractions-caseins $\left(\alpha_{\mathrm{S}_{1}-}, \alpha_{\mathrm{S} 2^{-}}, \beta-\right.$, and $\left.\mathrm{k}-\mathrm{CN}\right)$, and whey proteins ( $\beta$-lactoglobulin, $\beta$-LG; $\alpha$-lactalbumin, $\alpha$-LA) —estimated using the multi-trait genomic best linear unbiased prediction method and expressed variously as milk content $(\mathrm{g} / 100 \mathrm{~g}$ milk), percentage of milk nitrogen $(\% \mathrm{~N})$ and daily yield per cow $(\mathrm{g} / \mathrm{d})$. The results showed that the genetic parameter estimates varied according to how the milk protein fractions were expressed. Heritability estimates for the caseins and whey protein fractions expressed as daily yields were lower than when they were expressed as proportions and contents, revealing important differences in genetic outcomes. The proportion and the content of $\beta-\mathrm{CN}$ were negatively correlated with the proportions and contents of $\alpha_{\mathrm{S} 1}-\mathrm{CN}, \alpha_{\mathrm{S} 2}-\mathrm{CN}$, and $\mathrm{k}-\mathrm{CN}$, while the daily yield of $\beta-\mathrm{CN}$ was negatively correlated with the daily yields of $\alpha_{\mathrm{S} 1}-\mathrm{CN}$ and $\alpha_{\mathrm{S} 2}-\mathrm{CN}$. The Spearman's rank correlations and the coincidence rates between the various predicted genomic breeding values (GEBV) for the milk protein fractions expressed in different ways indicated that these differences had a significant effect on the ranking of the animals. The results suggest that the way milk protein fractions are expressed has implications for breeding programs aimed at improving milk nutritional and technological characteristics.
\end{abstract}

Keywords: genetic parameters; genetic correlations; caseins; whey proteins

\section{Introduction}

Milk protein fractions affect milk-derived products in terms of quality, milk coagulation ability and cheese yield, and therefore have a marked economic impact on the dairy industry [1]. The major milk protein fractions in milk are four caseins $(\mathrm{CN}), \alpha_{\mathrm{S1}^{-}}, \alpha_{\mathrm{S} 2^{-}}, \beta-$ and ${ }_{\mathrm{K}-} \mathrm{CN}$, and two whey proteins, 
$\alpha$-lactalbumin $(\alpha$-LA) and $\beta$-lactoglobulin ( $\beta$-LG), which together account for approximately $90 \%$ of total milk protein fractions [2] and play a key role in determining milk technological properties. Changes in milk protein composition can affect curd formation and cheese yield [3]. Milk protein fractions could therefore be included in the selection criteria in dairy cattle breeding programs aimed at improving cheese-making-related traits, assuming use of a rapid and effective method such as Fourier Transform Infrared (FTIR) spectroscopy for the determination of these traits at the population level [4]. Modifying the milk protein composition might offer also an opportunity to improve the nutritional value of milk [5].

From the animal breeding perspective, increasing the potential of cows to produce milk with greater amounts of casein could in turn increase the cheese-making aptitude of the milk $[1,6]$. However, if these traits are to be included in the selection indices of dairy cattle, thorough knowledge of their mutual relationships is required in order to design selection strategies that positively affect milk quality and cheese-making aptitude [3,7]. Several studies have reported genetic parameters for milk protein fractions expressed as percentage of total protein or as percentage of milk and investigated their mutual relationships $[3,5,8-10]$. However, to our knowledge, information regarding biological and genetic implications of using different ways of expression for milk proteins (assessed using the same analytical method, the same population and breed) in the animal breeding context is still scarce.

We hypothesized that different ways of expressing milk protein fractions (as either qualitative or quantitative data) could lead to differences not only in the genetic parameters for these traits, but also in the estimated genomic breeding values, which could in turn lead to re-ranking of the top animals. It is, therefore, crucial that these differences are taken into account when developing effective selection strategies in dairy cattle. Therefore, using a multi-trait framework we estimated the genetic parameters of milk protein fractions-four caseins ( $\beta-\mathrm{CN}, \mathrm{k}-\mathrm{CN}, \alpha_{\mathrm{S} 1}-\mathrm{CN}$, and $\alpha_{\mathrm{S} 2}-\mathrm{CN}$ ), and two whey proteins (WP: $\alpha$-LA and $\beta$-LG) —in Italian Brown Swiss dairy cattle, and compared the resulting data variously expressed as g of protein secreted per day $(\mathrm{g} / \mathrm{d})$, percentage of nitrogen $(\% \mathrm{~N})$ and $\mathrm{g} / \mathrm{L}$ of milk $(\mathrm{g} / \mathrm{L})$.

\section{Materials and Methods}

\subsection{Ethics Approval}

The cows included in the current study belonged to commercial private farms and were not subjected to any invasive procedures. Milk and blood samples were previously collected during routine milk recording coordinated by technicians from the Breeders' Association of Trento Province (Italy), and were hence certified by the local authority.

\subsection{Phenotypic and Genotypic Information}

Milk samples were collected once from 1,264 Italian Brown Swiss cows belonging to 85 commercial herds during the evening milking. Details of the animals included in the study are reported in Bittante et al. [11] and Cecchinato et al. [12]. Somatic cell counts were assessed using a Fossomatic FC counter (Foss Electric A/S) and converted to somatic cell scores (SCS) by logarithmic transformation, as proposed by Ali and Shook [13]. Milk quality traits were measured for total nitrogen, casein, and urea nitrogen (MUN) using a MilkoScan FT6000 apparatus (Foss Electric A/S, Hillerød, Denmark). The casein fractions $\left(\alpha_{\mathrm{S} 1}-\mathrm{CN}, \alpha_{\mathrm{S} 2}-\mathrm{CN}, \beta-\mathrm{CN}\right.$ and $\left.k-\mathrm{CN}\right)$ and whey proteins $(\alpha-\mathrm{LA}$ and $\beta-\mathrm{LG})$ were determined by validated reversed-phase high-performance liquid chromatography (RP-HPLC), as described by Bonfatti et al. [14]. Total casein $(\mathrm{CN})$ was defined as the sum of the casein fractions $(\beta-\mathrm{CN}, \mathrm{k}-\mathrm{CN}$, $\alpha_{\mathrm{S} 1}-\mathrm{CN}$, and $\alpha_{\mathrm{S} 2}-\mathrm{CN}$ ), and total whey protein (WP) as the sum of $\alpha$-LA and $\beta$-LG. Milk protein fractions were expressed as (i) the percentage of the total milk nitrogen content $(\% \mathrm{~N})$, (ii) $\mathrm{g} / \mathrm{L}$ of milk $(\mathrm{g} / \mathrm{L})$, and (iii) $\mathrm{g}$ of protein secreted per day $(\mathrm{g} / \mathrm{d})$, a measure that accounted for the cows' milk production levels. The milk protein fractions underwent phenotypic quality control to remove observations more than three standard deviations below or above the mean of the herd; a boxplot of the phenotypic values for the milk casein fractions can be found in Supplementary Information Figure S1. 
A total of 1050 cows were genotyped using the Illumina Bovine SNP50 v.2 BeadChip (Illumina Inc., San Diego, CA, USA). Genotypes underwent quality control to exclude the sexual chromosome regions. Autosomal SNP markers with minor allele frequencies (MAF) lower than 0.05, that deviated significantly from the Hardy-Weinberg equilibrium $\left(P \leq 10^{-5}\right)$ or had a call rate lower than 0.95 were removed. A total of 989 animals and 37,519 SNP markers were retained in the genomic dataset.

\subsection{Statistical Analysis}

A principal component analysis (PCA) was carried out to reveal possible population substructures in the study population. The principal components were computed with the gaston R package [15], and the animals were clustered into two groups; the first two components were considered co-variables in order to correct the population effect (Supplementary Information: Figure S2).

A multi-trait genomic best linear unbiased prediction (GBLUP) model was used to infer the genetic parameters for each set of traits separately (i) milk yield and milk protein fractions $(\beta-C N, k-C N$, $\alpha_{\mathrm{S} 1}-\mathrm{CN}, \alpha_{\mathrm{S} 2}-\mathrm{CN}, \beta-\mathrm{LG}$, and $\alpha$-LA) expressed as g/L; (ii) crude protein content and milk protein fractions expressed as $\% \mathrm{~N}$; (iii) milk protein fractions expressed as $\mathrm{g} / \mathrm{L}$, and iv) for the total protein, total casein $(\mathrm{CN})$ and total whey protein (WP) expressed as $\mathrm{g} / \mathrm{L}, \% \mathrm{~N}$ and $\mathrm{g} / \mathrm{d}$, according to the following model:

$$
y=X \beta+Z a+e
$$

where $y$ is the matrix for phenotypic information for the traits being investigated; $\beta$ is the vector of fixed effects defined by days in milk ( 6 classes: class 1, less than 60 days; class 2, 60-120 days; class 3, 121-180 days; class 4, 181-240 days; class 5, 241-300 days; class 6, more than 300 days), parity of the cow (4 classes: $1,2,3, \geq 4)$, and herd-date effect $(n=85)$, and the first two principal components as a linear co-variable to correct for population sub-structures; $a$ is the vector of additive genetic effects; $X$ and $Z$ are the incidence matrices relating $\mathbf{y}$ to effects $\beta$ and $\boldsymbol{a}$, respectively.

The additive genetic and residual effects were assumed to be normally distributed: $a=\left\{\mathrm{a}_{\mathrm{i}}\right\} \sim M N\left(\mathbf{0}, \Sigma_{g} \otimes \mathbf{G}\right)$ and $\mathrm{e}=\left\{\mathrm{e}_{\mathrm{ij}}\right\} \sim \operatorname{MN}\left(\mathbf{0}, \Sigma_{\boldsymbol{e}} \otimes \mathbf{I}\right)$, where $\Sigma_{g}=\left[\begin{array}{ccc}\sigma_{a 1}^{2} & \cdots & \sigma_{a 1, n} \\ \vdots & \ddots & \vdots \\ \sigma_{a 1, n} & \cdots & \sigma_{a n}^{2}\end{array}\right]$ and $\Sigma_{e}=\left[\begin{array}{ccc}\sigma_{e 1}^{2} & \cdots & 0 \\ \vdots & \ddots & \vdots \\ 0 & \ldots & \sigma_{e n}^{2}\end{array}\right]$ are the variance matrices for the additive genetic and residual effects, respectively; I is the identity matrix; and $\mathrm{G}$ is the genomic relationship matrix according to Van Raden [16]. The $\mathrm{G}$ matrix was constructed as follows: $G=M M^{\prime} q$ where $M$ is the SNP matrix assuming 0,1 , and 2 for genotypes $\mathrm{AA}, \mathrm{AB}$, and $\mathrm{BB}$; and $q$ is a weighting factor given as $q=1 / \sum_{j=1}^{n} 2 p_{j}\left(1-p_{j}\right)$, where $p_{j}$ is the second allele frequency of the $j$-th SNP marker.

\subsection{Genetic Parameters}

Genetic parameters were obtained with the average information restricted maximum likelihood procedure using a multi-trait animal model and the AIREMLF90 program of the BLUPF90 family [17].

Heritability estimates $\left(h_{a}^{2}\right)$ for the $\mathrm{CN}$ fractions $\left(\alpha_{\mathrm{S1}^{-}}, \alpha_{\mathrm{S}^{-}}, \beta-\right.$, and $\left.\mathrm{k}-\mathrm{CN}\right)$ and WP fractions ( $\beta$-LG and $\alpha$-LA), and for the total protein, casein $(\mathrm{CN})$, and whey protein (WP) contents, proportions, and daily yields were determined as: $h_{a}^{2}=\frac{\sigma_{a}^{2}}{\sigma_{a}^{2}+\sigma_{e}^{2}}$, where $\sigma_{a}^{2}$ and $\sigma_{e}^{2}$ are the genetic and residual variances, respectively. The correlations among the milk protein fractions were calculated as: $r_{a}=\frac{\hat{\sigma}_{a m, n}}{\sqrt{\hat{\sigma}_{m}^{2} \times \hat{\sigma}_{n}^{2}}}$. To assess the impact on animal rankings of expressing milk proteins qualitatively (\%N) or quantitatively (g/100g M and $\mathrm{g} / \mathrm{d}$ ), we calculated the Spearman's correlations among the genomic breeding values (GEBV) for each trait expressed in the three different ways $(\mathrm{g} / \mathrm{L}, \% \mathrm{~N}$ and $\mathrm{g} / \mathrm{d})$, and assessed the overlap among the top $5 \%$ of animals with the highest GEBV for each trait. The GEBV was calculated as 
the sum of the predicted SNP effects, as GEBV $V_{i}=\sum_{j=1}^{k} M_{i k} \hat{w}_{k}$, where $\hat{w}_{k}$ is the effect of the $k$-th SNP marker, using the predictf90 program of the BLUPF90 family [17].

\section{Results}

\subsection{Descriptive Statistics}

The descriptive statistics for the contents, proportions and daily yields of the milk protein fractions (caseins and whey proteins), milk crude protein content, and milk production are shown in Table 1. The cows produced an average of $24.70 \pm 7.68 \mathrm{~kg}$ milk. The average contents of the caseins were $9.41 \pm 1.20\left(\alpha_{\mathrm{S} 1}-\mathrm{CN}\right), 11.79 \pm 1.39(\beta-\mathrm{CN}), 3.47 \pm 0.68(\mathrm{k}-\mathrm{CN})$, and $3.37 \pm 0.57\left(\alpha_{\mathrm{S} 2}-\mathrm{CN}\right) \mathrm{g} / \mathrm{L}$. The average contents of the whey proteins were $3.19 \pm 0.70(\beta-\mathrm{LG})$, and $0.87 \pm 0.18(\alpha-\mathrm{LA}) \mathrm{g} / \mathrm{L}$. The milk protein fraction proportion was $87.67 \% \mathrm{~N}$, with caseins accounting for $76.62 \% \mathrm{~N}$ and whey protein for $11.05 \% \mathrm{~N}$. As expected, the milk caseins with the highest proportions were $\beta-\mathrm{CN}$ and $\alpha_{\mathrm{S} 1}-\mathrm{CN}$. The average proportions of the casein fractions were $32.22 \pm 2.38\left(\alpha_{\mathrm{S} 1}-\mathrm{CN}\right), 25.71 \pm 1.71(\beta-\mathrm{CN}), 9.52 \pm 1.39(\kappa-\mathrm{CN})$, and $9.17 \pm 1.05\left(\alpha_{S_{2}}-\mathrm{CN}\right) \% \mathrm{~N}$. The average proportions of the whey proteins $\beta$-LG and $\alpha$-LA were $8.66 \pm 1.47$ and $2.39 \pm 0.48 \% \mathrm{~N}$, respectively. Regarding daily yields, casein fractions secreted into the milk were $289.48 \pm 81.02\left(\alpha_{\mathrm{S} 1}-\mathrm{CN}\right), 230.58 \pm 72.18(\beta-\mathrm{CN}), 84.63 \pm 27.76(\mathrm{k}-\mathrm{CN})$, and $83.07 \pm 26.95$ $\left(\alpha_{\mathrm{S} 2}-\mathrm{CN}\right) \mathrm{g} / \mathrm{d}$; whey fractions secreted into the milk were $78.04 \pm 27.02(\beta-\mathrm{LG})$, and $21.64 \pm 8.71(\alpha$-LA) $\mathrm{g} / \mathrm{d}$. With respect to the phenotypic values, the highest variability was observed for daily yields compared with proportions and contents.

Table 1. Descriptive statistics for milk production, somatic cell scores, and milk proteins in Brown Swiss cattle.

\begin{tabular}{|c|c|c|c|c|c|c|}
\hline Trait $^{1}$ & $\mathbf{N}$ & Mean & Min & $\operatorname{Max}$ & SD & V.C. \\
\hline Milk yield $(\mathrm{kg} / \mathrm{d})$ & 981 & 24.87 & 5.91 & 45.33 & 7.28 & 29.27 \\
\hline \multicolumn{7}{|c|}{ Protein fraction contents $(g / L)$} \\
\hline Major protein fractions & 983 & 32.07 & 22.90 & 42.21 & 3.49 & 10.88 \\
\hline Major caseins & 983 & 28.03 & 19.94 & 36.90 & 2.97 & 10.59 \\
\hline$\alpha_{\mathrm{S} 1}-\mathrm{CN}$ & 987 & 9.41 & 5.80 & 12.99 & 1.20 & 12.75 \\
\hline$\alpha_{\mathrm{S} 2}-\mathrm{CN}$ & 986 & 3.37 & 1.98 & 5.11 & 0.57 & 16.91 \\
\hline$\beta-C N$ & 985 & 11.79 & 8.11 & 16.02 & 1.39 & 11.79 \\
\hline $\mathrm{k}-\mathrm{CN}$ & 984 & 3.47 & 1.36 & 5.53 & 0.68 & 19.59 \\
\hline Major whey proteins & 981 & 4.05 & 1.76 & 6.26 & 0.77 & 19.01 \\
\hline$\alpha-\mathrm{LA}$ & 982 & 0.87 & 0.38 & 1.42 & 0.18 & 20.69 \\
\hline$\beta$-LG & 988 & 3.19 & 1.15 & 5.27 & 0.70 & 21.94 \\
\hline Crude protein $(\mathrm{g} / \mathrm{L})$ & 985 & 36.60 & 25.80 & 48.40 & 4.10 & 10.79 \\
\hline \multicolumn{7}{|c|}{ Protein fraction proportions $(\% N)$} \\
\hline Major protein fractions & 980 & 87.67 & 81.77 & 93.55 & 2.25 & 2.57 \\
\hline Major caseins & 981 & 76.62 & 73.27 & 79.83 & 1.24 & 1.62 \\
\hline$\alpha_{\mathrm{S} 1}-\mathrm{CN}$ & 985 & 25.71 & 20.55 & 30.91 & 1.71 & 6.65 \\
\hline$\alpha_{\mathrm{S} 2}-\mathrm{CN}$ & 979 & 9.17 & 6.26 & 12.58 & 1.05 & 11.45 \\
\hline$\beta-C N$ & 976 & 32.22 & 25.97 & 39.41 & 2.38 & 7.39 \\
\hline $\mathrm{k}-\mathrm{CN}$ & 985 & 9.52 & 5.02 & 13.52 & 1.39 & 14.60 \\
\hline Major whey proteins & 979 & 11.05 & 6.69 & 15.46 & 1.52 & 13.76 \\
\hline$\alpha-\mathrm{LA}$ & 983 & 2.39 & 1.03 & 3.81 & 0.48 & 20.08 \\
\hline$\beta$-LG & 978 & 8.66 & 4.08 & 13.37 & 1.47 & 16.97 \\
\hline \multicolumn{7}{|c|}{ Protein fraction daily yields $(\mathrm{g} / \mathrm{d})$} \\
\hline Major protein fractions & 986 & 787.44 & 218.68 & 1370.19 & 225.67 & 28.66 \\
\hline Major caseins & 984 & 687.76 & 191.33 & 847.99 & 95.75 & 13.92 \\
\hline$\alpha_{\mathrm{S} 1}-\mathrm{CN}$ & 983 & 230.58 & 46.07 & 431.04 & 72.18 & 31.30 \\
\hline$\alpha_{\mathrm{S} 2}-\mathrm{CN}$ & 987 & 83.07 & 15.73 & 163.49 & 26.95 & 32.44 \\
\hline$\beta-\mathrm{CN}$ & 984 & 289.48 & 75.78 & 543.91 & 81.02 & 27.99 \\
\hline $\mathrm{k}-\mathrm{CN}$ & 984 & 84.63 & 11.42 & 169.78 & 27.76 & 32.80 \\
\hline
\end{tabular}


Table 1. Cont.

\begin{tabular}{ccccccc}
\hline Trait $^{\mathbf{1}}$ & $\mathbf{N}$ & Mean & Min & Max & SD & V.C. \\
\hline Major whey proteins & 983 & 99.68 & 21.36 & 190.73 & 33.11 & 33.21 \\
$\alpha$-LA & 983 & 21.64 & 4.01 & 47.97 & 8.71 & 40.25 \\
$\beta$-LG & 985 & 78.04 & 15.11 & 159.48 & 27.02 & 34.62 \\
\hline
\end{tabular}

CN: casein; $\beta$-LG: $\beta$-lactoglobulin; $\alpha$-LA: $\alpha$-lactalbumin; g/d: grams of protein secreted per day; $\% \mathrm{~N}$ : percentage of nitrogen; $\mathrm{g} / \mathrm{L}$ : grams per $\mathrm{L}$ of milk; Major protein fractions: sum of the whey proteins and caseins; Major caseins: sum of the casein fractions $\left(\beta-\mathrm{CN}+\kappa^{-}-\mathrm{CN}+\alpha_{\mathrm{S} 1}-\mathrm{CN}+\alpha_{\mathrm{S} 2}-\mathrm{CN}\right)$; Major whey proteins: sum of the whey protein fractions $(\beta-\mathrm{LG}+\alpha$-LA); V.C.: variance coefficient.

\subsection{Genetic Parameters}

The heritability estimate for milk yield was low $(0.12 \pm 0.027$; Table 2$)$. The heritability estimate for total whey proteins was slightly higher than for total caseins (Table 2). The genetic variance component estimates for caseins $\left(\alpha_{\mathrm{S1}^{-}}, \alpha_{\mathrm{S} 2^{-}}, \beta-\right.$ and $\left.\mathrm{k}_{\mathrm{K}} \mathrm{CN}\right)$ and whey proteins ( $\alpha$-LA and $\left.\beta-\mathrm{LG}\right)$ expressed as contents, proportions and daily yields differed substantially, providing strong evidence for different genetic outcomes (Table 2). The most important differences were between casein and whey protein daily yields and their contents and proportions (Table 2). The heritability estimates for $\alpha$-LA, whether for content, proportion or daily yield, were similar, with values of $0.21 \pm 0.0074(\mathrm{~g} / \mathrm{L}), 0.23 \pm 0.0081(\% \mathrm{~N})$ and $0.23 \pm 0.0078(\mathrm{~g} / \mathrm{d})$, respectively. The heritability estimates for $\beta-\mathrm{CN}$ exhibited the largest differences, with values of $0.59 \pm 0.0042$ for content, $0.78 \pm 0.0037$ for proportion, and $0.22 \pm 0.0025$ for daily yield (Table 2).

Table 2. Estimates (and standard errors) of genetic $\left(\sigma_{g}^{2}\right)$, and phenotypic $\left(\sigma_{p}^{2}\right)$ variances, and heritabilities $\left(h^{2}\right)$ for milk production and milk protein fractions.

\begin{tabular}{|c|c|c|c|}
\hline Trait & $\sigma_{g}^{2}$ & $\sigma_{p}^{2}$ & $h^{2}$ \\
\hline Milk yield $(\mathrm{kg} / \mathrm{d})$ & $2.79^{(0.892)}$ & $22.09^{(1.256)}$ & $0.12^{(0.033)}$ \\
\hline \multicolumn{4}{|c|}{ Protein fraction contents $(\mathrm{g} / \mathrm{L})$} \\
\hline Major protein fractions & $2.41^{(0.020)}$ & $6.07^{(0.094)}$ & $0.39^{(0.007)}$ \\
\hline Major caseins & $1.68^{(0.045)}$ & $4.41^{(0.088)}$ & $0.38^{(0.009)}$ \\
\hline$\alpha_{\mathrm{S} 1}-\mathrm{CN}$ & $0.51^{(0.002)}$ & $0.92^{(0.007)}$ & $0.55^{(0.001)}$ \\
\hline$\alpha_{\mathrm{S} 2}-\mathrm{CN}$ & $0.05^{(0.001)}$ & $0.18^{(0.009)}$ & $0.27^{(0.002)}$ \\
\hline$\beta-\mathrm{CN}$ & $0.64^{(0.002)}$ & $1.08^{(0.005)}$ & $0.59^{(0.004)}$ \\
\hline $\mathrm{k}-\mathrm{CN}$ & $0.18^{(0.007)}$ & $0.33^{(0.015)}$ & $0.55^{(0.005)}$ \\
\hline Major whey proteins & $0.12^{(0.003)}$ & $0.29^{(0.012)}$ & $0.43^{(0.005)}$ \\
\hline$\alpha-\mathrm{LA}$ & $0.003^{(0.000)^{*}}$ & $0.014^{(0.000)^{*}}$ & $0.21^{(0.007)}$ \\
\hline$\beta$-LG & $0.12^{(0.001)}$ & $0.24^{(0.008)}$ & $0.53^{(0.006)}$ \\
\hline Crude protein $(g / L)$ & $0.36^{(0.007)}$ & $0.82^{(0.06)}$ & $0.44^{(0.06)}$ \\
\hline \multicolumn{4}{|c|}{ Protein fraction proportions $(\% N)$} \\
\hline Major protein fractions & $0.84^{(0.013)}$ & $2.07^{(0.023)}$ & $0.40^{(0.009)}$ \\
\hline Major caseins & $0.37^{(0.054)}$ & $1.01^{(0.068)}$ & $0.37^{(0.009)}$ \\
\hline$\alpha_{\mathrm{S} 1}-\mathrm{CN}$ & $1.20^{(0.003)}$ & $2.06^{(0.066)}$ & $0.58^{(0.009)}$ \\
\hline$\alpha_{\mathrm{S} 2}-\mathrm{CN}$ & $0.23^{(0.002)}$ & $0.80^{(0.018)}$ & $0.29^{(0.008)}$ \\
\hline$\beta-C N$ & $3.67^{(0.004)}$ & $4.69^{(0.092)}$ & $0.78^{(0.003)}$ \\
\hline $\mathrm{k}-\mathrm{CN}$ & $1.10^{(0.009)}$ & $1.83^{(0.081)}$ & $0.60^{(0.006)}$ \\
\hline Major whey proteins & $0.56^{(0.010)}$ & $1.29^{(0.082)}$ & $0.43^{(0.011)}$ \\
\hline$\alpha-\mathrm{LA}$ & $0.02^{(0.003)}$ & $0.11^{(0.022)}$ & $0.23^{(0.008)}$ \\
\hline$\beta-L G$ & $0.63^{(0.003)}$ & $1.20^{(0.045)}$ & $0.53^{(0.005)}$ \\
\hline \multicolumn{4}{|c|}{ Protein fraction daily yields ( $g / d)$} \\
\hline Major protein fractions & $283.60^{(1.206)}$ & $2015.45^{(1.348)}$ & $0.15^{(0.004)}$ \\
\hline Major caseins & $207.47^{(0.985)}$ & $1320.91^{(1.055)}$ & $0.14^{(0.007)}$ \\
\hline$\alpha_{\mathrm{S} 1}-\mathrm{CN}$ & $285.35^{(2.578)}$ & $1284.45^{(17.086)}$ & $0.25^{(0.002)}$ \\
\hline$\alpha_{\mathrm{S} 2}-\mathrm{CN}$ & $52.60^{(0.231)}$ & $258.12^{(6.345)}$ & $0.20^{(0.009)}$ \\
\hline
\end{tabular}


Table 2. Cont.

\begin{tabular}{cccc}
\hline Trait & $\sigma_{\boldsymbol{g}}^{2}$ & $\boldsymbol{\sigma}_{\boldsymbol{p}}^{2}$ & $\boldsymbol{h}^{2}$ \\
\hline$\beta-\mathrm{CN}$ & $521.10^{(2.739)}$ & $2334.14^{(16.226)}$ & $0.22^{(0.002)}$ \\
K-CN & $105.65^{(0.380)}$ & $357.63^{(3.469)}$ & $0.29^{(0.001)}$ \\
Major whey proteins & $90.81^{(0.029)}$ & $340.66^{(0.832)}$ & $0.21^{(0.007)}$ \\
$\alpha$-LA & $5.45^{(0.020)}$ & $23.47^{(0.679)}$ & $0.23^{(0.007)}$ \\
$\beta$-LG & $97.09^{(0.353)}$ & $256.29^{(4.904)}$ & $0.38^{(0.003)}$ \\
\hline
\end{tabular}

CN: casein; $\beta$-LG: $\beta$-lactoglobulin; $\alpha$-LA: $\alpha$-lactalbumin; g/d: grams of protein secreted per day; $\% \mathrm{~N}$ : percentage of nitrogen; $\mathrm{g} / \mathrm{L}$ : grams per L of milk; Major protein fractions: sum of the whey proteins and caseins; Major whey proteins: sum of the whey protein fractions $(\beta-\mathrm{LG}+\alpha$-LA); Major caseins: sum of the casein fractions $(\beta-\mathrm{CN}+$ $\left.\mathrm{k}-\mathrm{CN}+\alpha_{\mathrm{S} 1}-\mathrm{CN}+\alpha_{\mathrm{S} 2}-\mathrm{CN}\right) ;{ }^{(0.000)^{*}}$ : a standard error below 0.0001 .

Average heritability estimates for the milk protein fractions varied depending on whether they were expressed as contents, proportions or daily yields (Table 2). The highest heritability estimates were for $\beta-C N$ content and proportion $\left(h^{2}=0.59\right.$ and $h^{2}=0.78$, respectively), while the highest heritability for daily yield was for $\beta$-LG $\left(h^{2}=0.38\right)$. However, $\beta$-LG content and proportion had the same heritability estimate $\left(\mathrm{h}^{2}=0.53\right)$, which was higher than that for daily yield. The heritability estimates for milk protein daily yield were around $46.13 \%$ lower than for milk protein content, and around $48.76 \%$ lower than for the proportion (Table 2). The heritability estimates for $\mathrm{k}-\mathrm{CN}, \alpha_{\mathrm{S} 1}-\mathrm{CN}$, and $\alpha_{\mathrm{S} 2}-\mathrm{CN}$ proportions were slightly higher than those for casein content.

\subsection{Genetic Correlations}

The genetic correlations for milk protein fraction contents $(\mathrm{g} / \mathrm{L})$ ranged from $-0.48(\beta-\mathrm{CN}$ and $\mathrm{k}-\mathrm{CN})$ to $0.74\left(\alpha_{\mathrm{S} 2}-\mathrm{CN}\right.$ and $\alpha_{\mathrm{S} 1}-\mathrm{CN}$; Table 3). Milk protein content exhibited weak to moderate negative correlations with milk yield, except for $\alpha_{S_{1}}-\mathrm{CN}$ which was positively correlated (0.22). Low to moderate genetic correlations were found between the milk protein fraction proportions $(\% \mathrm{~N})$ and crude protein (CP), which were positive for ${ }_{k}-\mathrm{CN}(0.17)$ and $\beta$-LG $(0.18)$, and negative for $\alpha_{\mathrm{S} 1}-\mathrm{CN}$ $(-0.41), \alpha_{\mathrm{S} 2}-\mathrm{CN}(-0.15), \beta-\mathrm{CN}(-0.25)$ and $\alpha-\mathrm{LA}(-0.50)$ (Table 3). Genetic correlations for milk protein fraction proportions $(\% \mathrm{~N})$ ranged from $-0.78(\beta-\mathrm{CN}$ and $\kappa-\mathrm{CN})$ to $0.67\left(\alpha_{\mathrm{S} 2}-\mathrm{CN}\right.$ and $\left.\alpha-\mathrm{LA}\right)$, and for daily yields they ranged from $-0.30(\beta-\mathrm{CN}$ and $\kappa-\mathrm{CN})$ to $0.85\left(\alpha_{\mathrm{S} 2}-\mathrm{CN}\right.$ and $\alpha_{\mathrm{S} 1}-\mathrm{CN}$; Table 3$)$. High, positive genetic associations were found between $\alpha_{S_{2}}-\mathrm{CN}$ and $\alpha_{S 1}-\mathrm{CN}$ in terms of contents and daily yields, while moderate positive values were found for their proportions.

The estimated additive genetic correlations between $\beta-\mathrm{CN}$ and $\mathrm{k}-\mathrm{CN}$ were moderate and negative for contents and daily yields ( -0.48 and -0.30 , respectively), high and negative for proportions $(-0.78$; Table 3$)$. The genetic correlations between the $\beta-\mathrm{CN}$ proportion and the $\alpha_{\mathrm{S} 1}-\mathrm{CN}, \alpha_{\mathrm{S} 2}-\mathrm{CN}$, and $\beta$-LG proportions were negative, but positive for daily yields. The $\beta-\mathrm{CN}$ content exhibited negative genetic correlations with the $\alpha_{\mathrm{S} 1}-\mathrm{CN}$ and $\alpha_{\mathrm{S} 2}-\mathrm{CN}$ contents, but a positive genetic correlation with $\beta$-LG content. The $\beta$-LG proportion exhibited low, negative genetic correlations with the $\beta-C N$ and $\mathrm{k}-\mathrm{CN}$ proportions ( -0.23 and -0.35 , respectively), and low, positive genetic correlations with the $\alpha_{\mathrm{S} 1}-\mathrm{CN}$ and $\alpha_{\mathrm{S} 2}-\mathrm{CN}$ proportions ( 0.25 and 0.23 , respectively). On the other hand, $\beta$-LG content and daily yield were positively associated with $\beta-\mathrm{CN}$ and $\mathrm{k}-\mathrm{CN}$ contents and daily yields, ranging from 0.17 to 0.37 . However, the genetic correlations between $\beta$-LG daily yield and $\alpha_{S 1}-\mathrm{CN}$ and $\alpha_{\mathrm{S} 2}-\mathrm{CN}$ daily yields were moderate ( 0.61 and 0.47 , respectively), and were also moderate for contents ( 0.56 and 0.34 , respectively).

The $\alpha$-LA daily yield showed a null genetic correlation with $\kappa$-CN daily yield, and low genetic correlations with the $\mathrm{k}-\mathrm{CN}$ proportion (0.14) and content (0.21; Table 3). The genetic correlations between the whey protein $\alpha$-LA and the caseins $\beta-\mathrm{CN}, \alpha_{\mathrm{S} 1}-\mathrm{CN}, \alpha_{\mathrm{S} 2}-\mathrm{CN}$, and $\beta$-LG were weakly to moderately positive for proportions $(\% \mathrm{~N})$, weakly negative to highly positive for contents $(\mathrm{g} / \mathrm{L})$, and moderately to highly positive for daily yields (g/d; Table 3). 
Table 3. Estimates of genetic correlations (above diagonal) and phenotypic correlations (below diagonal; standard error) among milk protein fractions.

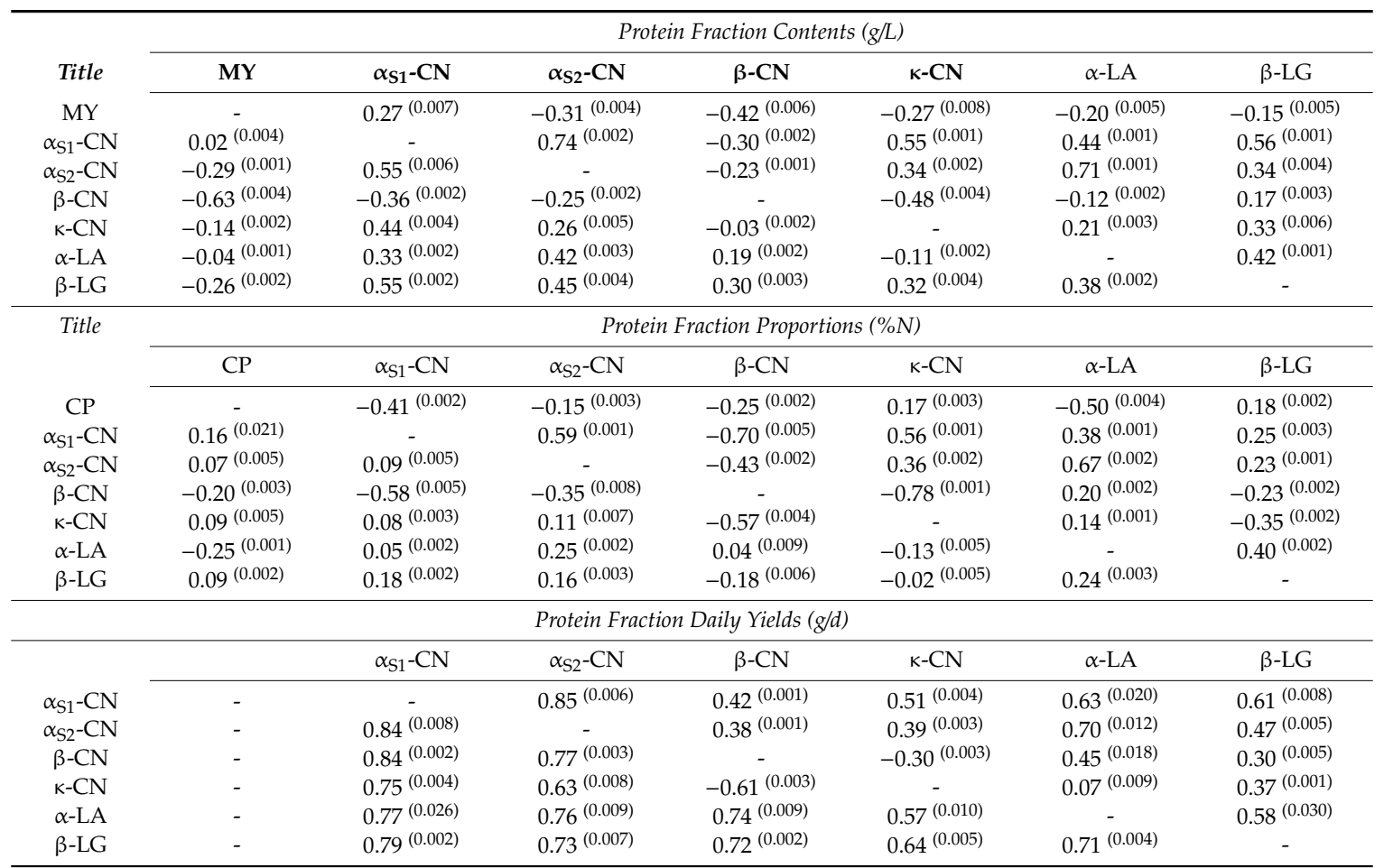

$C P$ : Crude protein (g/L); MY: Milk yield (kg/d); CN: casein; $\beta$-LG: $\beta$-lactoglobulin; $\alpha$-LA: $\alpha$-lactalbumin; g/d: grams of protein secreted per day; $\% \mathrm{~N}$ : percentage of nitrogen; $\mathrm{g} / \mathrm{L}$ : grams per $\mathrm{L}$ of milk.

\subsection{Phenotypic Correlations}

Phenotypic correlations among the milk protein fractions expressed in different ways tended to be in the same direction as the genetic correlations (Table 3). Overall, the phenotypic correlation estimates for milk protein fraction proportions were weaker than the genetic correlations but were higher for daily yields. All protein fraction contents had weak negative phenotypic correlations with milk yield, except for $\beta-\mathrm{CN}$, which had the strongest correlation $(-0.63)$. The estimated phenotypic correlations between milk yield and milk protein content tended to be in the same direction as the estimated genetic correlations, but lower, except for $\beta-\mathrm{CN}$ and $\beta$-LG (Table 3). Crude protein correlated negatively with the $\beta$-CN and $\alpha$-LA proportions, but positively with $\alpha_{\mathrm{S}_{1}}-\mathrm{CN}$ and $\alpha_{\mathrm{S} 2}-\mathrm{CN}$. Null phenotypic associations were observed between the $\beta-\mathrm{CN}$ and $\alpha$-LA proportions, the $\kappa-\mathrm{CN}$ and $\alpha_{\mathrm{S} 1}-\mathrm{CN}$ proportions, the $\alpha_{\mathrm{S} 1}-\mathrm{CN}$ and $\alpha_{\mathrm{S} 2}-\mathrm{CN}$ proportions, and the $\beta-\mathrm{CN}$ and $\mathrm{k}-\mathrm{CN}$ contents (Table 3 ). We found the environmental correlations to be high among milk protein fraction daily yields, moderate among milk protein contents, and weak-moderate among milk protein proportions (Table S1).

\subsection{Spearman's Correlations}

The rank correlations between the predicted genomic breeding values (GEBV) for the milk protein fractions expressed in different ways ranged from 0.68 (between $\mathrm{k}-\mathrm{CN}$ daily yield and content) to 0.93 (between $\beta$-LG proportion and content; Figures 1 and 2). The Spearman's correlation estimates show that alterations to the ranking of animals based on their GEBV for milk protein fractions are to be expected when these traits are differently expressed.

The Spearman's correlations among the GEBV for the caseins expressed in different ways varied from medium to high (Figure 1A,C,E,G). These results show that animals are often reclassified according to how the caseins are expressed, which results in different coincidence rates between the top $5 \%$ of animals by GEBV (Figure 1B,D,F,H). Among the milk proteins, $\mathrm{k}-\mathrm{CN}$ was most frequently reclassified, and exhibited a lower number of overlaps among the top $5 \%$ of animals by GEBV (Figure 1D). In general, 
the top animals were less frequently re-ranked when milk proteins were expressed as contents and proportions than when they were expressed as daily yields (Figure 1).

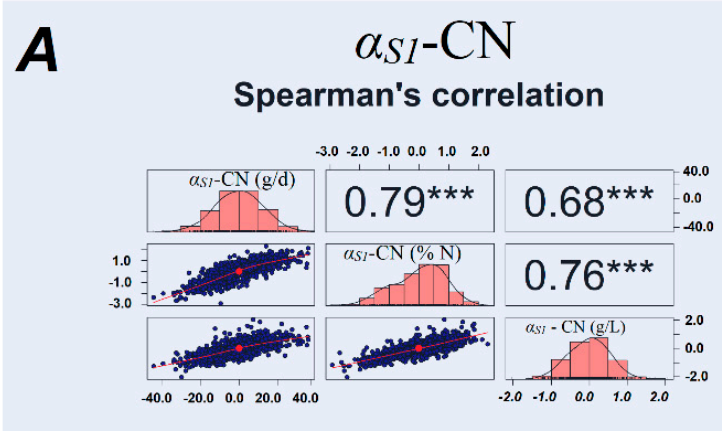

B

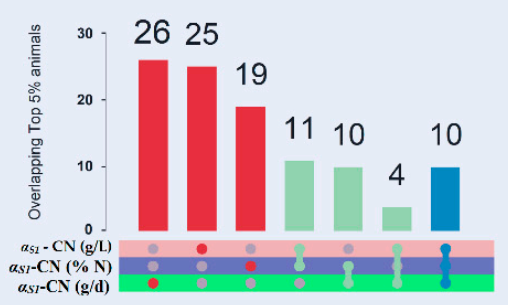

$E$
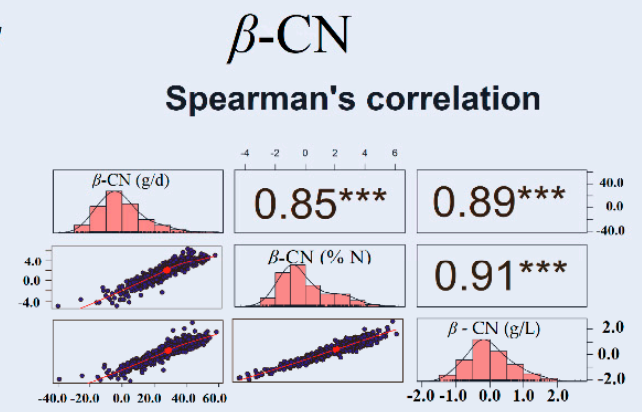

$\boldsymbol{F}$

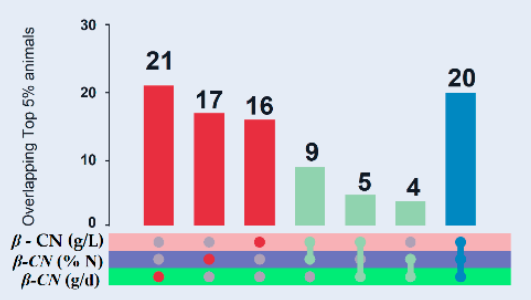

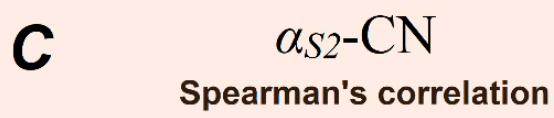

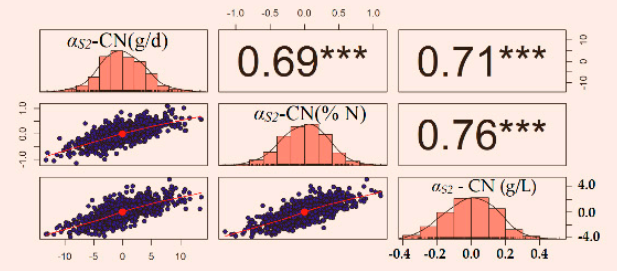

$D$

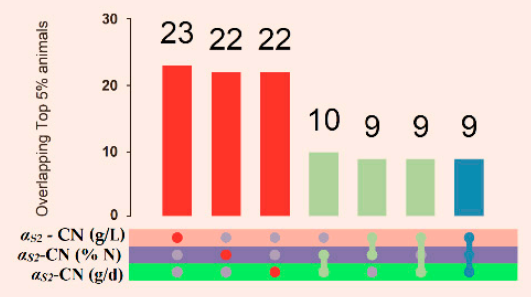

$\mathbf{G} \quad \kappa-\mathrm{CN}$

Spearman's correlation

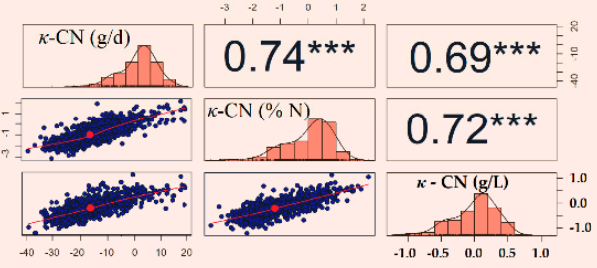

$\boldsymbol{H}$

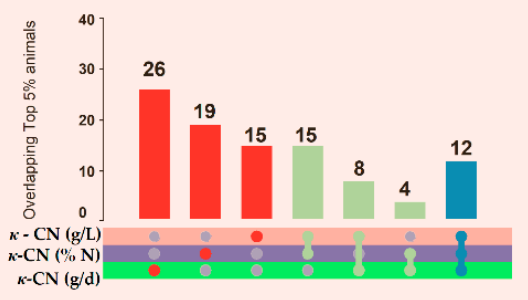

Figure 1. Genomic breeding value (GEBV) distributions (diagonal), Spearman's correlations of GEBV (upper triangle), and scatter plots (lower triangle) for $\alpha_{S 1}-\mathrm{CN}(\mathbf{A}), \alpha_{S 2}-\mathrm{CN}(\mathbf{C}), \beta-\mathrm{CN}(\mathbf{E})$ and $\mathrm{k}-\mathrm{CN}(\mathbf{G})$, specific to and shared across the $5 \%$ of animals $(n=50)$ with the highest GEBV for $\alpha_{S 1}-\mathrm{CN}(\mathbf{B}), \alpha_{\mathrm{S} 2}-\mathrm{CN}$ (D), $\beta-\mathrm{CN}(\mathbf{F})$, and $\mathrm{k}-\mathrm{CN}(\mathrm{H})$ contents $(\mathrm{g} / \mathrm{L})$, proportions $(\% \mathrm{~N})$, and daily yields $(\mathrm{g} / \mathrm{d})$.

The whey protein $\beta$-LG exhibited the highest Spearman's correlation coefficient $(r \geq 0.90)$ among the GEBV (Figure 2). These results show there is a high overlap among the top $5 \%$ animals for $\beta$-LG and a lower rate of re-ranking (Figure 2). On the other hand, the Spearman's correlations for $\alpha$-LA 
show that the animals are often re-ranked according to whether it is expressed as content, proportion or daily yield (Figure 2).
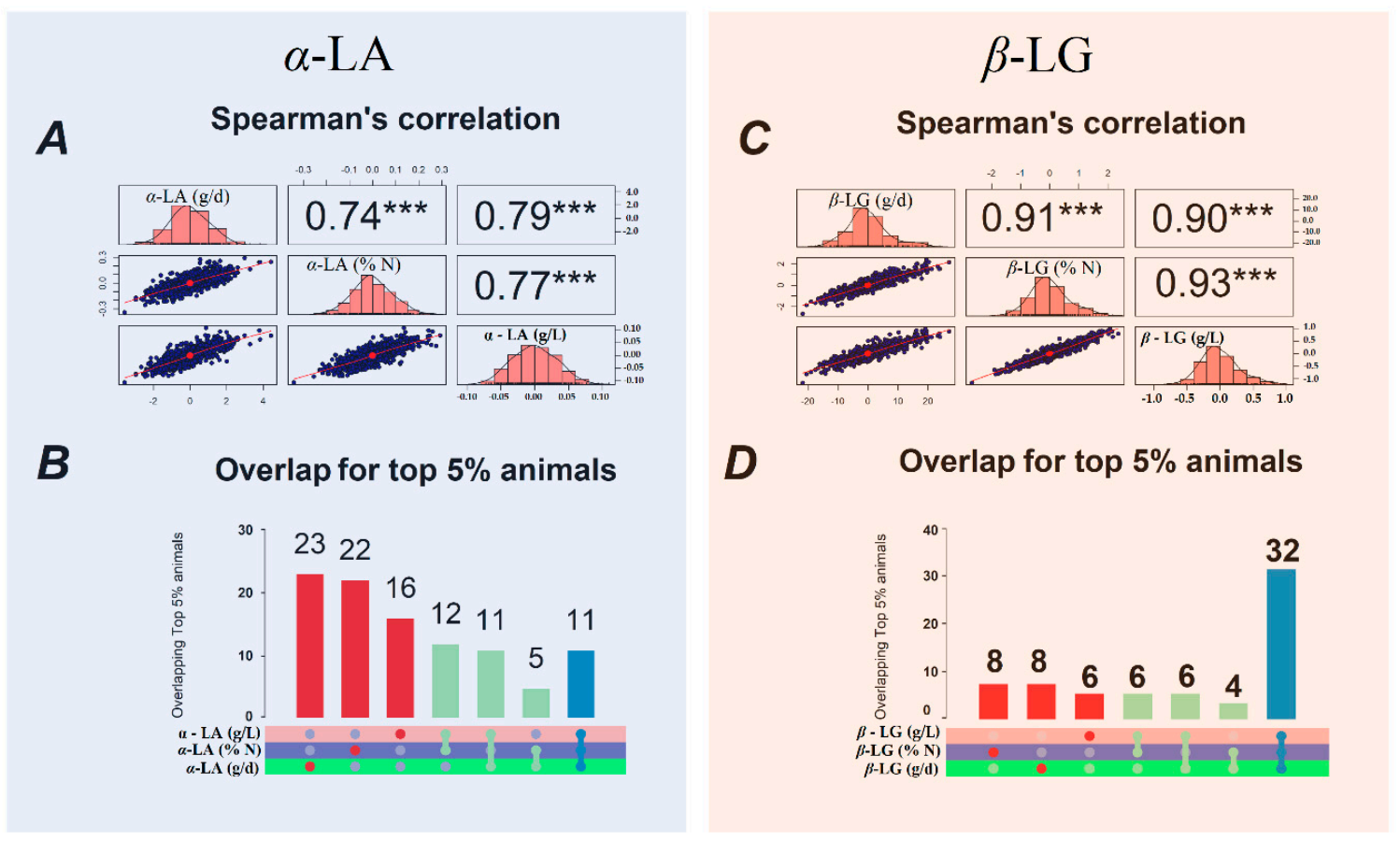

Figure 2. Genomic breeding value (GEBV) distributions (diagonal), Spearman's correlations of GEBV (top triangle), and scatter plots (lower triangles) for $\alpha$-LA (A) and $\beta$-LG (C), and the overlap between the $5 \%$ of animals $(n=50)$ with the highest GEBV for $\alpha$-LA $(\mathbf{B})$, and $\beta$-LG $(\mathbf{D})$ contents $(\mathrm{g} / \mathrm{L})$, proportions $(\% \mathrm{~N})$, and daily yields $(\mathrm{g} / \mathrm{d})$.

\section{Discussion}

We carried out this study in order to investigate potential differences in the genetic parameters of milk protein fractions (casein and whey proteins) according to whether they are measured as contents, proportions or daily yields. Milk protein composition is affected mainly by genetic factors, as well as by non-genetic factors. In this study, the caseins $\alpha_{\mathrm{S} 1}-\mathrm{CN}$ and $\beta-\mathrm{CN}$ were found in higher proportions than $\alpha_{S 2}-\mathrm{CN}$ and $k-\mathrm{CN}$, representing approximately $75.61 \%$ of the total casein content, in agreement with various studies on different dairy breeds [5,10,18,19]. Among the whey protein fractions, we found $\beta$-LG in amounts approximately 3.5 times that of $\alpha$-LA. This result is in agreement with data from previous studies $[9,19,20]$.

\subsection{Genetic Parameters}

The heritability estimates for casein and whey protein proportions indicate that a considerable part of the variation for these traits is influenced by the additive genetic effect (Table 2). Milk protein fraction daily yields exhibited lower heritability estimates than the proportions, due to the low heritability of single-test-day milk yields, and genetic progress would therefore be particularly slow for these traits. The higher heritabilities observed for $\mathrm{k}-\mathrm{CN}$ and $\beta-\mathrm{CN}$ proportions might be due to the fact that single protein fractions are highly regulated by the CSN2 - CSN3 haplotype [21]. Our findings are in agreement with those of Pegolo et al. [9] and Bonfatti et al. [3], who reported that the qualitative data obtained from milk protein fraction proportions resulted in higher estimates.

The lowest heritability estimates for milk protein proportions were for $\alpha$-LA (0.23), while the highest were for $\beta-\mathrm{CN}(0.78)$, in agreement with previous data [9]. Schopen et al. [5], however, obtained a higher heritability estimate for $\beta$-LG (0.80), and a lower one for $\beta-C N(0.25)$. These differences might be due to different breeds and allele frequencies affecting the milk protein content [22]. Some 
differences were found among the heritability estimates for the major caseins (from 0.78 for $\beta$-CN to 0.29 for $\left.\alpha_{\mathrm{S} 2}-\mathrm{CN}\right)$. These heritability estimates are directly affected by the genetic link between the $\mathrm{CN}$ haplotype and the proportions of these fractions [23]. Bonfatti et al. [3] reported a similar heritability estimate to ours of 0.28 for $\alpha_{\mathrm{S} 2}-\mathrm{CN}$, and Pegolo et al. [9] obtained a slightly one (0.36). In contrast, Schopen et al. [5] reported a much higher heritability for $\alpha_{\mathrm{S} 2}-\mathrm{CN}$ (0.73) in Dutch Holstein-Friesians.

The moderate heritability estimates for $\alpha$-LA content, proportion and daily yield (Table 2) were similar to the values reported by Gebreyesus et al. [8], confirming a combination of substantial genetic and environmental effects on the expression of this trait. Higher heritability estimates for $\alpha-\mathrm{LA}$ as a proportion have been reported in Dutch Holstein-Friesians (0.55) [5], in French Holstein (0.44), Montbéliarde (0.72) and Normande (0.53) [10], and in Danish Holsteins (0.40) and Danish Jerseys (0.44) [24] breeds, although with a standard error higher than ours. The heritability obtained in our study for $\beta$-LG as a proportion was moderate and consistent with previous results reported by Buitenhuis et al. [24] for Danish Holstein (0.58), Gebreyesus et al. [8] for Danish Holstein (0.56), Pegolo et al. [9] for Italian Brown Swiss (0.558) and Sanchez et al. [10] for French Holstein (0.71), Montbéliarde (0.79) and Normande (0.72) breeds. On the other hand, Schopen et al. [5] obtained a higher mean heritability estimate (0.80), and Bonfatti et al. [3] a lower mean heritability estimate (0.34) than we did. These variations in heritability estimates across different studies may be partly due to different breeds, sample sizes, and statistical models used.

Differences in the genetic components were observed according to whether the milk proteins were measured as contents, proportions or daily yields (Table 2), which suggests that from a genetic perspective they could be considered as different traits. Measuring milk protein fractions in terms of daily yields seems to imply that their phenotypic expression is highly influenced by environmental factors. The lower heritability estimates for $\alpha$-LA could be partly due to greater environmental effects on its relative concentrations compared with other fractions. Our heritability results for casein and whey protein contents were higher than those reported by Bonfatti et al. [3], which ranged from 0.11 ( $\alpha$-LA) to $0.53(\mathrm{k}-\mathrm{CN})$. Sanchez et al. [10] found lower heritability estimates for $\alpha_{\mathrm{S} 1}-\mathrm{CN}, \beta-\mathrm{CN}$, and k-CN in the Normande (NO) and Holstein (HO) breeds, although they obtained higher heritabilities for the Montbéliarde breed.

Overall, the heritability estimates for milk protein fraction proportions were higher than those for contents and daily yields, which suggests that qualitative measures of these traits capture the influence of milk protein genotypes more effectively $[18,23]$. This seems to indicate that predictions of expected responses to selection for major casein and whey proteins might differ according to whether the milk proteins are expressed qualitatively or quantitatively. Therefore, a greater potential for genetic gain is expected when milk proteins are measured as proportions, which is supported by higher heritability estimates and higher predictive ability measured by the Pearson's correlation among the GEBV and corrected phenotype (Supplementary information Figure S3). The observed differences in the predictive ability for milk protein fractions expressed in different ways $(\mathrm{g} / \mathrm{L}, \% \mathrm{~N}$ and $\mathrm{g} / \mathrm{d}$ ) may be explained by different biological perspectives related to their genetic variation. Thus, considering milk proteins expressed as daily yields, which accounts for the cows' milk production levels, might reflect the combination of genetic and environmental factors.

\subsection{Genetic and Phenotypic Correlations}

The importance of estimating genetic and phenotypic correlations between milk protein fraction contents, proportions and daily yields is to gain a better understanding of how caseins and whey proteins might respond to selection in dairy cattle. The phenotypic correlations among milk protein fraction daily yields were higher than those among proportions and contents, providing further evidence of the greater effect of environmental factors. The differences in the phenotypic correlations according to whether the milk proteins were expressed as contents, proportions or daily yields may be explained by differences in the contributions of genetic and environmental effects. However, the same trend was observed in the genetic and phenotypic correlations for milk protein fractions. According to 
Cheverud [25] and Sodini et al. [26], similar directions for phenotypic and genetic correlations could be due to environmental effects acting in the same direction as the genetic effects.

The genetic relationships among the milk protein fraction contents, proportions and daily yields were expected, since caseins are clustered on BTA6 within a $250 \mathrm{~kb}$ region [27], and caseins and whey proteins have a common biological regulatory mechanism controlling their synthesis $[9,28]$. Indeed, the genomic region controlling casein and whey protein expression exhibits a considerable linkage disequilibrium [29]. There is a high positive genetic correlation between milk yield and milk protein content [30]. We found a lower positive genetic correlation between milk yield and the content of $\alpha_{S 1}-\mathrm{CN}$, one of the major milk protein fractions together with $\beta-\mathrm{CN}$. On the other hand, we found a moderate negative correlation between milk yield and $\beta-\mathrm{CN}$, and weak negative correlations between milk yield and the other milk protein fraction contents. These results indicate that selection for milk yield has little effect on the contents of individual milk proteins. A similar pattern was observed regarding the genetic correlations between crude protein and milk protein proportions, except for the correlation between crude protein and $\alpha$-LA and $\alpha_{S_{1}}-\mathrm{CN}$, which was moderate and negative in both cases. Selection for milk protein content is therefore expected to have a small to moderate effect on milk protein composition.

$\beta-\mathrm{CN}$ correlated negatively with $\mathrm{k}-\mathrm{CN}$, as proportions $(\mathrm{r}=-0.78)$ and as daily yields and contents $(r=-0.30)$, in agreement with Bonfatti et al. [3] and Sanchez et al. [10], who determined milk proteins as qualitative traits. On the other hand, Bonfatti et al. [3] and Schopen et al. [5] found null genetic correlations between $\beta-\mathrm{CN}$ and $\mathrm{k}-\mathrm{CN}$ contents in Dutch Holstein-Friesians $(\mathrm{r}=-0.04)$ and Simmentals $(r=0.08)$. Furthermore, Bonfatti et al. [3] looked at CSN2 - CSN3 haplotypes and $\beta$-LG genotype effects and found positive genetic correlations between $\beta-\mathrm{CN}$ and $\mathrm{k}-\mathrm{CN}(\mathrm{r}=0.66)$. This further confirms that milk protein fractions have common regulatory mechanism controlling their synthesis. The negative correlation observed between $\beta-\mathrm{CN}$ and $\mathrm{k}-\mathrm{CN}$ could be ascribed to the existence of some compensatory regulatory mechanisms, due to the remarkably strong linkage among genes coding for these milk protein variants.

We found negative genetic associations between $\beta-\mathrm{CN}$ and $\alpha_{\mathrm{S1}}-\mathrm{CN}$, and between $\beta-\mathrm{CN}$ and $\alpha_{\mathrm{S} 2}-\mathrm{CN}$ when expressed as proportions ( $\mathrm{r}=-0.70$ and -0.43 , respectively) and as contents $(\mathrm{r}=-0.30$ and -0.23 , respectively), but positive correlations when expressed as daily yields $(r=0.42$ and 0.38 , respectively). These results are in agreement with the literature $[3,8]$. However, other authors obtained null estimates between $\beta-\mathrm{CN}$ and $\alpha_{\mathrm{S} 1}-\mathrm{CN}$ [5]. It has been suggested that increasing the $\beta-\mathrm{CN}$ concentration in milk is associated with a decrease in the $\alpha_{\mathrm{s} 1}-\mathrm{CN}$ content, which seems to be caused by a competitive synthesis effect $[18,21-23,31]$. However, expressing milk proteins as proportions tend to generate negative covariances among them, especially in the case of $\beta-\mathrm{CN}$ and $\alpha_{\mathrm{S} 1}-\mathrm{CN}$ which are the major milk proteins in bovine milk.

The moderate and high genetic correlations among $\alpha_{\mathrm{S} 1}-\mathrm{CN}, \alpha_{\mathrm{S} 2}-\mathrm{CN}$, and $\mathrm{k}-\mathrm{CN}$ proportions, contents and daily yields indicate that using sires selected for these traits should result in progenies able to produce milk enriched in these casein fractions. The $\mathrm{k}-\mathrm{CN}$ fraction has a strong positive effect on milk coagulation, curd firming, and the syneresis process; similarly, the $\alpha_{\mathrm{S} 1}-\mathrm{CN}$ fraction in milk has a favorable effect on curd firmness. On the other hand, the $\alpha_{S_{2}-}-\mathrm{CN}$ fraction seems to have the opposite effect to $\alpha_{S 1}-\mathrm{CN}$, since it delays milk gelation, and reduces the maximum curd firmness reached within $90 \mathrm{~min}$ as well as syneresis [20]. Sanchez et al. [10] also reported positive genetic associations among $\alpha_{\mathrm{S} 1}-\mathrm{CN}, \alpha_{\mathrm{S} 2}-\mathrm{CN}$, and $\kappa-\mathrm{CN}$ contents and proportions, with values ranging from 0.84 to 0.98 . Several studies have shown that differences in the promoter region of CSN3 may give rise to different effects on the content of the $\alpha_{\mathrm{S} 1}-\mathrm{CN}$ and $\alpha_{\mathrm{S} 2}-\mathrm{CN}$ fractions $[22,23,31]$.

The genetic correlations between the proportion of the major whey protein $\beta$-LG and the casein fractions $\beta-\mathrm{CN}$ and $\mathrm{k}-\mathrm{CN}$ were negative $(-0.23$ and -0.35 , respectively). Regarding daily yields and contents, the genetic associations between $\beta-\mathrm{LG}$ and the casein fractions $\beta-\mathrm{CN}$ and $\mathrm{k}-\mathrm{CN}$ were positive, with values ranging from 0.17 to 0.37 . Sanchez et al. [10] reported negative correlations between the proportion of $\beta-\mathrm{LG}$ and the proportions of $\beta-\mathrm{CN}$ and $\mathrm{k}-\mathrm{CN}$ ranging from -0.20 to -0.75 in three 
breeds; with regard to contents, however, the same authors obtained positive associations, with values ranging from 0.07 to 0.58 . Heck et al. [21] and Bobe et al. [23] observed that $\beta$-LG variants affected determination of its proportion in milk, and also affected $\beta-\mathrm{CN}$ and $\mathrm{k}-\mathrm{CN}$ proportions of the total milk protein. These correlations indicate that selection for lower proportions of $\beta$-LG should increase the proportion of $\mathrm{k}-\mathrm{CN}$ in milk, with positive effects on milk coagulation $[18,20,32]$. Highly significant interactions between $\beta-\mathrm{CN}, \mathrm{k}-\mathrm{CN}$ and $\beta$-LG have been reported in literature which could be explained by the existence of epistatic effects between the genes coding for these proteins [33].

We obtained positive genetic associations between $\beta-\mathrm{LG}$ and $\alpha_{\mathrm{S1}}-\mathrm{CN}$, and between $\beta$-LG and $\alpha_{\mathrm{S} 2}-\mathrm{CN}$. Bonfatti et al. [3] found a null genetic correlation between the proportion of $\beta$-LG and the proportions of $\alpha_{\mathrm{S} 1}-\mathrm{CN}$ and $\alpha_{\mathrm{S} 2}-\mathrm{CN}$; however, these authors found low to moderate correlations between them in terms of contents $(r=0.26$ and $r=0.35$, respectively). Regarding the CSN2 - CSN3 haplotypes and $\beta$-LG genotype effects, we obtained higher estimates, which provides further evidence that $\beta$-LG controls the proportion of $\alpha_{S 1}-\mathrm{CN}$ in milk [3]. In agreement with this, several studies have shown that the haplotypes with positive effects on the $\beta$-LG percentage reduce the $\alpha_{\mathrm{S} 1}$-CN percentage in milk [18,21-23].

We found a null association between $\alpha$-LA and $\mathrm{k}-\mathrm{CN}$ daily yields $(\mathrm{r}=0.07)$, and a weak negative association between $\alpha$-LA and $\beta-\mathrm{CN}$ contents $(\mathrm{r}=-0.16)$. In our study, population, we observed positive genetic associations ranging from low-moderate to high between the $\alpha$ - LA content and the $\mathrm{k}$ - CN, $\alpha_{S 1}-\mathrm{CN}, \alpha_{\mathrm{S} 2}-\mathrm{CN}$, and $\beta$ - LG contents, although Bonfatti et al. [3] reported lower estimates. On the other hand, Gebreyesus et al. [8] found a negative association between $\alpha$-LA and $\alpha_{S 1}-\mathrm{CN}$ $(r=-0.32)$. Nevertheless, Sanchez et al. [10] reported a low association between $\alpha$-LA and $\beta-\mathrm{CN}(0.18)$, and a high association between $\alpha$-LA and $\mathrm{k}-\mathrm{CN}(0.80)$. Moreover, we found moderate associations between $\alpha$-LA and $\beta-L G$ expressed as contents, proportions and daily yields, while several authors found genetic correlations ranging from negative $(r=-0.57)$ to low positive $(r=0.27)[3,5,8,10]$.

\subsection{Spearman's Correlations}

The Spearman's rank correlations between breeding values calculated with multi-trait models for casein and whey protein contents, proportions and daily yields were significant for $\alpha_{\mathrm{S} 1}-\mathrm{CN}, \alpha_{\mathrm{S} 2}-\mathrm{CN}$, ${ }_{\mathrm{K}}-\mathrm{CN}$, and $\alpha$-LA. In general, the correlations among milk protein fraction proportions and contents were higher than among daily yields (Figures 1 and 2). The rank correlations for casein fractions ranged from moderate $(r=0.68)$ to high $(r=0.91)$, indicating some differences in the animals selected based on GEBVs. The highest rank correlation was between the $\beta-C N$ proportion and content $(r=0.91)$, followed by that between daily yield and content $(\mathrm{r}=0.89)$. On the other hand, the greatest frequency of re-ranking of animals was observed for the $\alpha_{\mathrm{S} 2}-\mathrm{CN}$ and $\alpha$ - LA fractions, based on the Spearman's correlations and the overlap between the top $5 \%$ of animals.

The results of the rank correlation lead us to speculate that expressing milk proteins in different ways has an impact on the outcome of selection strategies in dairy cattle. It is of note that the lower Spearman's correlations for $\alpha_{\mathrm{S} 1}-\mathrm{CN}, \alpha_{\mathrm{S} 2}-\mathrm{CN}$ and $\alpha$-LA might be due to an effect of unknown environmental and non-additive factors leading to the differences in the ranking of animals for these traits according to whether they are expressed as proportions, contents or daily yields.

\section{Conclusions}

Our study shows that expressing milk protein fractions variously as proportions, contents or daily yields can lead to different genetic outcomes. In particular, protein fraction proportions may be associated with a more effective response to selection than contents or daily yields. The differences in the patterns of genetic and phenotypic correlations for caseins and whey proteins suggest that different ways of expressing them capture different biological processes. The Spearman's correlations and coincidence rates indicate substantial differences in genetic variation, and major effects as a result of re-ranking the animals. This information will be useful in developing breeding programs aimed at improving milk quality and cheese-making ability. Before that; however, the occurrence of possible 
adverse effects of selection based on milk protein composition on cow's fitness, health, and welfare should be further investigated. Moreover, for large-scale phenotyping of milk protein fractions, fast and cost-effective tools such as Fourier transform infrared (FT-IR) spectroscopy might represent an effective alternative to the gold standard analytical methodology for routinely measuring these traits at a population level for breeding purposes.

Supplementary Materials: The following are available online at http://www.mdpi.com/2076-2615/10/2/336/s1, Figure S1: Boxplot of the phenotypic values for milk protein fractions casein fractions $\left(\alpha_{\mathrm{S} 1}, \alpha_{\mathrm{S} 2}, \beta\right.$, and $\left.\mathrm{k}-\mathrm{CN}\right)$ and whey proteins ( $\beta$ - LG and $\alpha$ - LA) expressed as (i) gram secreted per day (g/d); (ii) percentage of total milk nitrogen content $(\% \mathrm{~N})$ and (iii) gram/L of milk $(\mathrm{g} / \mathrm{L})$ after phenotypic control. Figure $\mathrm{S} 2-(\mathrm{A})$ Number of $\mathrm{k}$ clusters to identify the population structure and (B) A principal components analysis revealed two breeding subgroups of Brown Swiss cattle based on the genomic kinship coefficient. Table S1: Estimates of environmental correlation for milk protein fraction estimated as a percentage of total milk nitrogen $(\mathrm{N})$ content using genomic information, Figure S3: Predictive ability assessed in the multi-trait model by Pearson's correlations between genomic breeding values $(\mathrm{GEBV})$ and adjusted phenotypes $\left(\mathrm{y}^{*}\right)$ for milk protein fractions contents $(\mathrm{g} / \mathrm{L})$, proportions $(\% \mathrm{~N})$ and daily yields $(\mathrm{g} / \mathrm{d})$.

Author Contributions: A.C. and G.B. conceived and led the coordination of the study. L.F.M.M., S.P., and A.C. performed the study design. S.P. and V.B. contributed to the milk protein fractions separate and estimate. L.F.M.M. and A.C. contributed to the statistical analysis. L.F.M.M. led the data analysis and manuscript preparation. All authors have read and agreed to the published version of the manuscript.

Funding: This research was funded by University of Padova (DOR), grant number DOR1917910/19.

Acknowledgments: The authors wish to thank the Trento Province (Italy), the Italian Brown Swiss Cattle Breeders Association (ANARB, Verona, Italy) and the Superbrown Consortium of Bolzano and Trento for financial and technical support.

Conflicts of Interest: The authors declare no conflict of interest, as well as, the funders had no role in the design of the study; in the collection, analyses, or interpretation of data or in the decision to publish the results.

\section{References}

1. Wedholm, A.; Larsen, L.B.; Lindmark-Månsson, H.; Karlsson, A.H.; Andrén, A. Effect of Protein Composition on the Cheese-Making Properties of Milk from Individual Dairy Cows. J. Dairy Sci. 2006, 89, 3296-3305. [CrossRef]

2. Holland, B.; Rahimi Yazdi, S.; Ion Titapiccolo, G.; Corredig, M. Short communication: Separation and quantification of caseins and casein macropeptide using ion-exchange chromatography. J. Dairy Sci. 2010, 93, 893-900. [CrossRef] [PubMed]

3. Bonfatti, V.; Cecchinato, A.; Gallo, L.; Blasco, A.; Carnier, P. Genetic analysis of detailed milk protein composition and coagulation properties in Simmental cattle. J. Dairy Sci. 2011, 94, 5183-5193. [CrossRef] [PubMed]

4. Ferragina, A.; de los Campos, G.; Vazquez, A.I.; Cecchinato, A.; Bittante, G. Bayesian regression models outperform partial least squares methods for predicting milk components and technological properties using infrared spectral data. J. Dairy Sci. 2015, 98, 8133-8151. [CrossRef]

5. Schopen, G.C.B.; Heck, J.M.L.; Bovenhuis, H.; Visker, M.H.P.W.; van Valenberg, H.J.F.; van Arendonk, J.A.M. Genetic parameters for major milk proteins in Dutch Holstein-Friesians. J. Dairy Sci. 2009, 92, 1182-1191. [CrossRef]

6. Cecchinato, A.; Ribeca, C.; Maurmayr, A.; Penasa, M.; De Marchi, M.; Macciotta, N.P.P.; Mele, M.; Secchiari, P.; Pagnacco, G.; Bittante, G. Effects of $\beta$-lactoglobulin, stearoyl-coenzyme A desaturase 1, and sterol regulatory element binding protein gene allelic variants on milk production, composition, acidity, and coagulation properties of Brown Swiss cows. J. Dairy Sci. 2012, 95, 450-454. [CrossRef]

7. Dadousis, C.; Cipolat-Gotet, C.; Bittante, G.; Cecchinato, A. Inferring genetic parameters on latent variables underlying milk yield and quality, protein composition, curd firmness and cheese-making traits in dairy cattle. Animal 2018, 12, 224-231. [CrossRef]

8. Gebreyesus, G.; Lund, M.S.; Janss, L.; Poulsen, N.A.; Larsen, L.B.; Bovenhuis, H.; Buitenhuis, A.J. Multi-trait estimation of genetic parameters for milk protein composition in the Danish Holstein. J. Dairy Sci. 2016, 99, 2863-2866. [CrossRef] 
9. Pegolo, S.; Mach, N.; Ramayo-Caldas, Y.; Schiavon, S.; Bittante, G.; Cecchinato, A. Integration of GWAS, pathway and network analyses reveals novel mechanistic insights into the synthesis of milk proteins in dairy cows. Sci. Rep. 2018, 8, 566. [CrossRef]

10. Sanchez, M.P.; Ferrand, M.; Gelé, M.; Pourchet, D.; Miranda, G.; Martin, P.; Brochard, M.; Boichard, D. Genetic parameters for milk protein composition predicted using mid-infrared spectroscopy in the French Montbéliarde, Normande, and Holstein dairy cattle breeds. J. Dairy Sci. 2017, 100, 6371-6375. [CrossRef]

11. Bittante, G.; Cipolat-Gotet, C.; Malchiodi, F.; Sturaro, E.; Tagliapietra, F.; Schiavon, S.; Cecchinato, A. Effect of dairy farming system, herd, season, parity, and days in milk on modeling of the coagulation, curd firming, and syneresis of bovine milk. J. Dairy Sci. 2015, 98, 2759-2774. [CrossRef] [PubMed]

12. Cecchinato, A.; Albera, A.; Cipolat-Gotet, C.; Ferragina, A.; Bittante, G. Genetic parameters of cheese yield and curd nutrient recovery or whey loss traits predicted using Fourier-transform infrared spectroscopy of samples collected during milk recording on Holstein, Brown Swiss, and Simmental dairy cows. J. Dairy Sci. 2015, 98, 4914-4927. [CrossRef]

13. Ali, A.K.A.K.A.; Shook, G.E.E. An Optimum Transformation for Somatic Cell Concentration in Milk. J. Dairy Sci. 1980, 63, 487-490. [CrossRef]

14. Bonfatti, V.; Grigoletto, L.; Cecchinato, A.; Gallo, L.; Carnier, P. Validation of a new reversed-phase high-performance liquid chromatography method for separation and quantification of bovine milk protein genetic variants. J. Chromatogr. A 2008, 1195, 101-106. [CrossRef] [PubMed]

15. Perdry, H.; Dandine-Roulland, L. Gaston-Genetic Data Handling (QC, GRM, LD, PCA) \& Linear Mixed Models. R Packag. 2018, 83, 1-29.

16. VanRaden, P.M. Efficient methods to compute genomic predictions. J. Dairy Sci. 2008, 91, 4414-4423. [CrossRef]

17. Misztal, I.; Tsuruta, S.; Lourenco, D.; Aguilar, I.; Legarra, A.; Vitezica, Z. Manual for BLUPF90 Family of Programs; University of Georgia: Athens, GA, USA, 2015.

18. Bonfatti, V.; Di Martino, G.; Cecchinato, A.; Vicario, D.; Carnier, P. Effects of $\beta$-K-casein (CSN2-CSN3) haplotypes and $\beta$-lactoglobulin (BLG) genotypes on milk production traits and detailed protein composition of individual milk of Simmental cows. J. Dairy Sci. 2010, 93, 3797-3808. [CrossRef]

19. Cipolat-Gotet, C.; Cecchinato, A.; Malacarne, M.; Bittante, G.; Summer, A. Variations in milk protein fractions affect the efficiency of the cheese-making process. J. Dairy Sci. 2018, 101, 8788-8804. [CrossRef]

20. Amalfitano, N.; Cipolat-Gotet, C.; Cecchinato, A.; Malacarne, M.; Summer, A.; Bittante, G. Milk protein fractions strongly affect the patterns of coagulation, curd firming, and syneresis. J. Dairy Sci. 2019, 102, 2903-2917. [CrossRef]

21. Heck, J.M.L.L.; Schennink, A.; Van Valenberg, H.J.F.F.; Bovenhuis, H.; Visker, M.H.P.W.P.W.; Van Arendonk, J.A.M.M.; Van Hooijdonk, A.C.M.M. Effects of milk protein variants on the protein composition of bovine milk. J. Dairy Sci. 2009, 92, 1192-1202. [CrossRef]

22. Gustavsson, F.; Buitenhuis, A.; Johansson, M.; Bertelsen, H.; Glantz, M.; Poulsen, N.; Lindmark Månsson, H.; Stålhammar, H.; Larsen, L.; Bendixen, C.; et al. Effects of breed and casein genetic variants on protein profile in milk from Swedish Red, Danish Holstein, and Danish Jersey cows. J. Dairy Sci. 2014, 97, 3866-3877. [CrossRef] [PubMed]

23. Bobe, G.; Beitz, D.C.; Freeman, A.E.; Lindberg, G.L. Effect of Milk Protein Genotypes on Milk Protein Composition and Its Genetic Parameter Estimates. J. Dairy Sci. 1999, 82, 2797-2804. [CrossRef]

24. Buitenhuis, B.; Poulsen, N.A.; Gebreyesus, G.; Larsen, L.B. Estimation of genetic parameters and detection of chromosomal regions affecting the major milk proteins and their post translational modifications in Danish Holstein and Danish Jersey cattle. BMC Genet. 2016, 17, 114. [CrossRef] [PubMed]

25. Cheverud, J.M. Quantitative genetics and developmental constraints on evolution by selection. J. Theor. Biol. 1984, 110, 155-171. [CrossRef]

26. Sodini, S.M.; Kemper, K.E.; Wray, N.R.; Trzaskowski, M. Comparison of genotypic and phenotypic correlations: Cheverud's conjecture in humans. Genetics 2018, 209, 941-948. [CrossRef]

27. Bevilacqua, C.; Helbling, J.C.; Miranda, G.; Martin, P. Translational efficiency of casein transcripts in the mammary tissue of lactating ruminants. Reprod. Nutr. Dev. 2006, 46, 567-578. [CrossRef]

28. Schopen, G.C.B.; Visker, M.H.P.W.; Koks, P.D.; Mullaart, E.; van Arendonk, J.A.M.; Bovenhuis, H. Whole-genome association study for milk protein composition in dairy cattle. J. Dairy Sci. 2011, 94, 3148-3158. [CrossRef] 
29. Huang, W.; Peñagaricano, F.; Ahmad, K.R.; Lucey, J.A.; Weigel, K.A.; Khatib, H. Association between milk protein gene variants and protein composition traits in dairy cattle. J. Dairy Sci. 2012, 95, 440-449. [CrossRef]

30. van Binsbergen, R.; Veerkamp, R.F.; Calus, M.P.L. Makeup of the genetic correlation between milk production traits using genome-wide single nucleotide polymorphism information. J. Dairy Sci. 2012, 95, 2132-2143. [CrossRef]

31. Jensen, H.B.; Poulsen, N.A.; Andersen, K.K.; Hammershøj, M.; Poulsen, H.D.; Larsen, L.B. Distinct composition of bovine milk from Jersey and Holstein-Friesian cows with good, poor, or noncoagulation properties as reflected in protein genetic variants and isoforms. J. Dairy Sci. 2012, 95, 6905-6917. [CrossRef]

32. Elofsson, U.M.; Paulsson, M.A.; Sellers, P.; Arnebrant, T. Adsorption during Heat Treatment Related to the Thermal Unfolding/Aggregation of $\beta$-Lactoglobulins A and B. J. Colloid Interface Sci. 1996, 183, 408-415. [CrossRef] [PubMed]

33. Molina, J.M.; Kramm, J.; Brito, B.C.; Carrillo, B.; Pinto, M.; Ferrando, A. Protein composition of milk from Holstein-Friesian dairy cows and its relationship with the genetic variants $\mathrm{A}$ and $\mathrm{B}$ of $\mathrm{k}$-casein and $\beta$-lactoglobulin (Part I). Int. J. Dairy Technol. 2006, 59, 183-187. [CrossRef]

(C) 2020 by the authors. Licensee MDPI, Basel, Switzerland. This article is an open access article distributed under the terms and conditions of the Creative Commons Attribution (CC BY) license (http://creativecommons.org/licenses/by/4.0/). 